\title{
THE IMAGE OF ION I. C. BRĂTIANU IN THE FOREIGN PRESS OF 1916
}

\author{
Gheorghe CALCAN \\ Petroleum-Gas University of Ploiești, Romania \\ calcangheorghe@yahoo.com
}

\begin{abstract}
Our paper aims to highlight the way Ion I. C. Brătianu was presented outside national borders in a fundamental moment of our national history, namely the integration of Romania into the operations of World War I in 1916. At that landmark moment, Ion I. C. Brătianu was Prime Minister of the country and was perceived abroad as the most powerful personality in the Romanian decisionmaking space, on whom the very decision to enter the war was hanging on. Foreign observers considered that Brătianu would not integrate with the war other than besides the military camp and in the moment that would definitely ensure their final victory. In order to sketch his image at international level we mainly used the information provided by the French press of the time (especially newspaper "Le Figaro").
\end{abstract}

\section{Keywords: Ion I. C. Brătianu, French press}

\section{Introduction}

Brătianu family represents a real political dynastsy of modern Romania, family that was involved in the landmark moments of the Romanian society's founding and development. Dimitrie and Ion C. Brătianu were on the barricades of the revolution in 1848 , Ion C. Brătianu took active part in the 1859 Union and in its consolidation. He was also considered to be the main pawn in bringing Prince Carol of Hohenzollern to Romania and in instaling the constitutional monarchy in our country.

Dimitie Brătianu, the brother of Ion C. Brătianu, the mayor of Bucharest in office at that time, organized a fastuous welcoming procession of the new ruler. Ion C. Brătianu was involved in the preparations for the national independence and led the country during the 1877-1878 War of Independence, as well as the efforts of the international consecration of this new political statute.

Son of Ion C. Brătianu, Ionel (Ion I. C. Brătianu) played a brilliant, demiurge-like role in founding and consolidating Greater

Romania. Head of the National Liberal Party (like his father), he campaigned in favour of the country's entry into World War and was involved in the formation of Greater Romania. As Prime Minister, Ion I. C. Brătianu headed the Romanian delegation at the Peace Conference in Paris in 1919-1920, where he pleaded for and managed to obtain the international recognition of the Great Union. His brother, Vintilă Brătianu, mayor of Bucharest, Finance Minister and deputy, stood out as a staunch supporter of the national dignity, which should be led by the liberal principle "by ourselves". The other brother, Constantin Brătianu, was a prominent liberal politician, MP and party leader.

Our paper aims at highlighting the role Ion I. C. Brătianu played in Romania joining World War I, and the way he was perceived by several international observers, especially by those of the French newspaper Le Figaro. 


\section{Ion I. C. Brătianu's image abroad in 1916}

After two years of neutrality, on $4 / 17$ August 1916, Romania signed the accession documents to the Entente. The Prime Minister in duty was Ion I. C. Brătianu, the main artisan of this moment, role that was well known and appreciated abroad. In this respect, journalists from Corriere d'Italia considered that "Brătianu acted as a true statesman, able to perfectly maintain his self-control and to be cold-blooded, yet open-mindded, when treating business" [1]. Ten days after this event, on 14/27 August 1916, Romania declared war to AustriaHungary and actually joined the operations of the worldwide conflagration. Romanian media appreciated that domestic fighting ceased and that at that moment "there was only one Romania fighting to be Greater Romania" [2]. An eyewitness of the events noted: "The enthusiasm was high throughout all population" [3].

The event was equally expected for by the international public opinion. Le Figaro devoted almost an entire issue, i.e. 29 August 1916, to the declaration of war and substantial comments on the event continued in the following issue of the publication. Obviously, documents, information and assessments on Brătianu were not omitted.

On this occasion, Aristide Briande, French Prime Minister, telegraphed Brătianu the following: "The whole French nation applauded the declaration by which Romania had courageously taken its place among the defenders of law and civilization.

I am happy to be their interpreter and that of the Government of the French Republic when sending to you our warmest congratulations.

As your noble country committed this great liberating act, I have no doubt that our common efforts for the triumph of law and civilization will not only ensure the Allied victory, but will also enable Romania to achieve its national aspirations" [4].
Asquith, Prime Minister of UK, telegraphed in his turn to Brătianu: "On behalf of the British government, I hasten to convey sincere congratulations to Your Excellency for the decision of the Romanian government to take an active part in this great struggle for freedom and justice, alongside the Allies.

Needless to assure Your Excellency of the profound friendship which has existed for so long between the peoples of our countries, relation that will be reinforced and strengthened by the remarkable decision taken by your King and Government" [5].

The telegram sent by his Italian counterpart to Brătianu, impressive due to its warm tone, evoked moments that had prepared the achievement of the Romanian Principalities Union, the personality of Ion C. Brătianu the father and recognized the righteousness of the national liberation struggle. It also provided small quotes from Mazzini and Brătianu - the father, such as: "In the name of Italy, I warmly welcome our sister nation for its decision to join the battle against our old assailant, alongside the allies fighting for the triumph of civilization.

«You are part of an immortal trunk and you have a mission of freedom and progress»", stated Giuseppe Mazzini in 1851, when addressing to the father of Your Excellency. There came the reply: "We are fighting for the rights of all; whoever the enemies of law may be, those will be our enemies. This cry of a prophetic war is today the cry that unites us in the same action.

Therefore, I deduce from this evocation of the two great patriots the wish and confidence in our victory" [5].

The recourse to such a glorious past also appeared in an article from Le Figaro, which highlighted the history of the Romanian-French relations, as well as the contribution Napoleon III of France had to the establishment of the Hohenzollern dynasty in Romania. In this context, there was evoked the friendship between Mrs. Cornu on one side and the French king, the 
Sigmaringen family and Brătianu himself on the other, as well as the role the French monarch played in the monarchy's establishment in Bucharest [6].

The article entitled La déclaration de guerre (Declaration of War), signed by A. Fitz Maurice appreciated that, by the decision to declare war on Austria-Hungary, "Mr. Brătianu proved that he was fully aware of the interests and legitimate aspirations of his country" [7]. Moreover, the journalist supported his considerations by quoting other international publications, namely Gazette de Francfort, which asserted that "Brătianu joined the Entente, without being in a life threatening danger, but in order to be beneficial for Romania" [7].

When analyzing comments from Le Figaro, one can identify and pinpoint two clear dominant ideas. The former was that Romania and explicitly Brătianu cleverly chose the moment for the country to join the war, and the latter, circumscribed to the former, stated that this decision would implicitly lead to the final victory of the Allies. This shows the great credit for the tactics, actions and decisions made in Bucharest by Brătianu.

In a substantial article from the French newspaper, it was emphasized the fact that Romania's decision to enter the war in 1916 had been very judicious, sparing the country of unnecessary efforts and losses. Furthermore, it was considered that "one can say that Mr. Brătianu kept Romania, for over two years, for the Entente, while a premature initiative would have offered Germanic powers the means not only to destroy a beautiful army, but also to access one of the richest granaries of the world, and one of the largest oil reservoirs" [6]. The French newspaper suggested a very flattering comparison between Brătianu and Richelieu, the Cardinal who knew to wait for the right moment that would lead France to its victory against the great powers of Europe. The attitude of Brătianu was also appreciated as being that of a true politician's, as he did not provide any details on his intentions prior to taking the final decision [6].

The articles from Le Figaro also provided information on the position that other French publications took when referring to Brătianu. L'Action française considered Romania's entering the war "a major event" and quoted Maximilian Harden's statements according to which "Mr. Brătianu will join the Entente Powers only when these will be able to guarantee its final victory. The Romanians will definitely join the winners" [8]. In its turn, the newspaper Le Gaulois, when advertising the news of Romania's entering the war, advised his readers: "Let us, therefore, be patient and trust in King Ferdinand and in Mr. Brătianu that gave such a brilliant proof of loyalty" [9].

Positive feedback on the decisional qualities of the Romanian Prime Minister can be identified even in German publications. Gazette de Francfort considered, even prior to the declaration of war against Austria-Hungary, that Romania and Brătianu will position, when taking decisions, on that part that will ensure their success, and not automatically by Germany's side [10]. Before the historical decision on 14/27 August 1916, the newspaper Germany announced in a somewhat surprising tone that "We can be sure that Mr. Brătianu will gladly join the Entente Powers, if they could guarantee the final victory" [10].

Greek press also appraised the policy of Brătianu and Romania's decision to attack Austria-Hungary. They showed that desperate Germanophile circles in Athens "hoped until the last moment for Romania to change their option or for the effect of German threats on Mr. Brătianu and King Ferdinand" [11].

After the declaration of war, military events followed their well-known course, with the tragedy and heroism of the years 19161917, with the upheaval of 1918 or with the moment of Romania's national unity [12, 13], episodes that are not, however, the topic of our paper. 


\section{Conclusions}

Our brief presentation highlighted several very significant nuances of Ion I. C. Brătianu's personality as reflected in the international press and in public opinion. Essentially, external assessments were not different from the ones in Romania, fact that reconfirms Ion I. C. Brătianu's skills, fortitude, patriotism, as well as his major role in promoting national interests in an astral moment of our national history

Both foreign media and policymaking circles from the Western countries were aware that Brătianu was the one to push the "buttons of the Romanian policy" and paid him high consideration. In 1916, an overwhelming majority of the international public opinion considered that the decision to be taken by Brătianu would ensure (or not) the victory in the World War.

Le Figaro, as well as most of the French newspapers and other important international journals, proved to be objective and sympathetic to the Romanian issue. The foreign press was very well informed in this respect, which praises the journalistic professionalism of the time. The appeal to history and to memory, the portraits of the Brătianu family, namely that of I. C. Brătianu - the father, Prime Minister in office, pinpoint the important role the entire Brătianu family played in the national awareness of Romania and represent an urge to respect personalities and moments form the past with perennial value.

To conclude, Ion I. C. Brătianu was unquestionably a demiurge that contributed to the building up of the Romanian national unity, completed in 1918, and to the consolidation of this statute in the years to come, merits acknowledged by his countrymen and foreigners alike.

\section{References}

[1] Academia Română/ Romanian Academy, Istoria Românilor/ The History of Romanians, vol. VII, tom II, De la Independență la Marea Unire (1878-1918/ From Independence to the Great Union), coordinator Gheorghe Platon, Bucharest, Enciclopedică Publishing House, 2003, p. 419.

[2] Ceasul hotărâror al României. Consiliul de Coroană de astăzi. In sfârşit/ The Turning Point in the Romanian History: The Crown Council, „Adevărul”, 15 August, 1916.

[3] Calcan, Gheorghe, Moşoiu, Cantemir, Profesorul şi senatorul Aurelian Moşoiu, o personalitate a lumii prahovenel The Professor and Senator Aurelian Moşoiu: A Personality of Prahova County, Ploiești, Printeuro Publishing House, 2003, Page 93.

[4] Aux Rois d'Italie et de Roumanie, „Le Figaro”, 29 Août, 1916.

[5] Entre Alliés, „Le Figaro”, 31 Août, 1916.

[6] Polybe, Du Tibre au Danube, „Le Figaro”, 29 Août, 1916.

[7] Fitz - Maurice, A., La déclaration de guerre, „Le Figaro”, 29 Août, 1916.

[8] La presse de ce matin. L'entrée en guerre de la Roumanie. L`Action française, „Le Figaro", 29 Août, 1916.

[9] La presse de ce matin. L'entrée en guerre de la Roumanie, „Le Figaro”, 29 Août, 1916.

[10] Opinions étrangéres, „Le Figaro”, 29 Août, 1916.

[11] En Grèce. La décision roumaine et l'opinion greque, „Le Figaro”, 29 Août, 1916.

[12] Popa, Mircea N., Primul război mondial 1914-1918/ The First World War1914-1918, Bucharest, Ştiinţifică şi Enciclopedică Publishing House, 1979.

[13] Kiriţescu, Constantin Istoria războiului pentru intregirea României 1916-1919/ The History of the Unification War 1916-1919, text revised by Costin Kiriţescu, Mircea N. Popa and Lucia Popa, Bucharest, Ştiinţifică şi Enciclopedică Publishing House, 1989. 